\title{
PENGEMBANGAN PERANGKAT PEMBELAJARAN MATEMATIKA MENGGUNAKAN MODEL PROBLEM BASED LEARNING UNTUK MEMFASILITASI KEMAMPUAN REPRESENTASI MATEMATIS PESERTA DIDIK
}

\author{
Ovemy Delfita $^{1}$, Nahor Murani Hutapea ${ }^{2}$, Atma Murni $^{3}$ \\ ${ }^{1,2,3}$ Program Magister Pendidikan Matematika, FKIP, Universitas Riau, Pekanbaru, Indonesia \\ ovemy.delfita6522@grad.unri.ac.id
}

\begin{abstract}
Abstrak
The ability of mathematical representation is an ability that students should have in order to assist in interpreting problems into verbal, visual, and symbolic forms. The low ability of students' mathematical representation and learning tools that are made by the teacher has not facilitated enough the ability of mathematical representation the main objective of this study. Researchers developed learning tools consisting of syllabus, lesson plans, and student worksheet using the Problem Based Learning model to improve students' mathematical representation skills. The development model used is the Borg and Gall's model. The instruments used were validation sheets and student response questionnaires. The data analysis technique used is the analysis of validity and practicality. The result of the percentage of validity shows that the learning device is included in the valid category with an average syllabus percentage of $92.18 \%$, RPP is $93.64 \%$ and LKPD is $93.06 \%$. The student response questionnaire analysis showed that the device was included in the very practical category with an average of 92.2\%. The tools developed by researchers have met the valid and practical categories to facilitate the mathematical representation abilities of students.
\end{abstract}

Keywords: Learning Tools, Mathematical Representation Ability, Problem Based Learning Model, Build Flat Side Space

\begin{abstract}
Abstrak
Kemampuan representasi matematis merupakan kemampuan yang harus dimiliki peserta didik guna membantu dalam menginterpretasikan masalah kedalam bentuk verbal, visual, dan simbolik. Rendahnya kemampuan representasi matematis peserta didik dan perangkat pembelajaran yang dibuat oleh guru belum memfasilitasi kemampuan representasi matematis yang menjadi tujuan utama dalam penelitian ini. Peneliti mengembangkan perangkat pembelajaran yang terdiri dari Silabus, RPP, dan LKPD menggunakan model Problem Based Learning untuk meningkatkan kemampuan representasi matematis peserta didik. Model pengembangan yang digunakan yaitu melalui model pengembangan Borg and Gall. Instrumen yang digunakan yaitu lembar validasi dan angket respon peserta didik. Teknik analisis data yang digunakan yaitu analisis kevalidan dan kepraktisan. Hasil persentase validitas menunjukkan bahwa perangkat pembelajaran termasuk dalam kategori valid dengan persentasi rata-rata silabus yaitu 92,18\%, RPP yaitu 93,64\% dan LKPD yaitu 93,06\%. Analisis angket respon peserta didik menunjukkan bahwa perangkat termasuk dalam kategori sangat praktis dengan rata-rata $92,2 \%$. Perangkat yang dikembangkan peneliti telah memenuhi kategori valid dan praktis untuk memfasilitasi kemampuan representasi matematis peserta didik.
\end{abstract}

Kata Kunci: Perangkat Pembelajaran, Kemampuan Representasi Matematis, Model Problem Based Learning, Bangun Ruang Sisi Datar

\section{PENDAHULUAN}

Tujuan pembelajaran matematika menurut kurikulum 2013 salah satunya yaitu peserta didik dapat mengkomunikasikan dan merepresentasikan gagasan/ide matematis melalui simbol, tabel, diagram, atau media lain untuk memperjelas suatu masalah (Permendikbud Nomor 58 Tahun 2014). Sejalan dengan itu, National Council of Teacher of Mathematics (2000) menyatakan bahwa terdapat lima kemampuan matematis yang harus dimiliki oleh peserta didik salah satunya yaitu kemampuan representasi (representations) matematis. 
Pengembangan Perangkat Pembelajaran Matematika Menggunakan Model Problem Based Learning Untuk Memfasilitasi Kemampuan Representasi Matematis Peserta Didik, Ovemy Delfita, Nahor Murani Hutapea, Atma Murni

Representasi matematis merupakan kemampuan dasar yang harus dimiliki oleh peserta didik dalam mengemukakan ide-idenya dalam bentuk simbol-simbol, kata-kata atau grafik. Dengan adanya representasi akan mempermudah peserta didik untuk memahami konsep dan menyelesaikan soal-soal matematis yang diberikan. Hal ini sejalan dengan pendapat Sabirin (2014), kemampuan representasi matematis adalah suatu bentuk interpretasi dari pemikiran peserta didik terhadap suatu masalah yang digunakan sebagai alat bantu dalam menemukan solusi dari permasalahan tersebut.

Namun pada kenyataannya tujuan pembelajaran matematika di Indonesia belum tercapai dengan baik, hal ini terlihat dari hasil studi internasional Programme for International Student Assessment (PISA) dan Trends in International Mathematics and Science Study (TIMSS). Hasil survey PISA 2015 menurut OECD 2016 (dalam Inayah, 2018) menunjukkan bahwa prestasi belajar peserta didik Indonesia pada mata pelajaran matematika berada di peringkat 63 dari 72 negara peserta. Menurut Inayah (2018) penyebab rendahnya prestasi peserta didik Indonesia dalam PISA adalah lemahnya kemampuan representasi matematis.

Persentase hasil skor pencapaian peserta didik Indonesia pada TIMSS 2015 untuk domain kognitif applying adalah $24 \%$ dari rata-rata International sebesar $48 \%$. Berdasarkan hasil survei TIMSS dan PISA salah satu faktor penyebab rendahnya kemampuan representasi matematis peserta didik di Indonesia yaitu peserta didik kurang terlatih dalam menyelesaikan soal-soal dengan karakteristik seperti soal-soal pada TIMSS dan PISA yang subtansinya kontekstual, menuntut penalaran, argumentasi dan kreativitas dalam penyelesaian (Wardhani, 2011).

Rendahnya kemampuan representasi matematis peserta didik juga didukung berdasarkan data hasil penelitian yang dilakukan (Murni, 2012) dengan sampel penelitian sebanyak 202 peserta didik SMPN di Kota Pekanbaru. Murni (2012) menyimpulkan bahwa rata-rata kemampuan representasi matematis seluruh sampel masih relatif rendah. Kemampuan representasi matematis yang dimaksud pada penelitian tersebut adalah kemampuan menjelaskan ide-ide matematika menggunakan simbol dalam bentuk pernyataan matematis/notasi matematis dan numerik/simbol aljabar.

Peneliti melakukan observasi, wawancara dengan guru mata pelajaran matematika dan wawancara dengan peserta didik kelas VIII SMPN 1 Siak Hulu. Berdasarkan hasil observasi dan wawancara menunjukkan bahwa kemampuan representasi matematis peserta didik masih tergolong rendah. Rendahnya kemampuan representasi matematis disebabkan siswa terbiasa mengerjakan soal sesuai contoh dan langkah-langkah penyelesaian seperti yang diberikan guru. Peserta didik diberikan soal-soal non rutin yang mengakibatkan kurang terlatihnya kemampuan representasi matematis (Sulastri, 2017).

Faktor lain yang menyebabkan kurangnya kemampuan representasi matematis peserta didik yaitu perangkat pembelajaran yang dibuat guru belum sesuai dengan standar proses dan belum memfasilitasi kemampuan representasi matematis untuk tercapaianya tujuan pembelajaran. Guru 
masih kurang memahami kemampuan yang harus dicapai peserta didik salah satunya kemampuan representasi matematis.

Beberapa hasil penelitian menunjukkan bahwa perangkat pembelajaran yang digunakan guru di Indonesia masih belum sesuai dengan standar proses pada Permendikbud Nomor 22 Tahun 2016. Seperti penelitian Tanjung dan Nababan (2018) yang melakukan observasi di SMA Se-Kuala Nagan Raya Aceh yaitu kurang sesuainya materi yang diajarkan dengan kompetensi dasar pada silabus, RPP yang dibuat belum sesuai dengan pembelajaran kurikulum 2013, dan tidak tersedianya lembar kerja peserta didik. Simanungkalit (2016) melakukan observasi di SMP Negeri 12 Pematangsiantar menunjukkan bahwa kegiatan pembelajaran pada RPP belum memuat pendekatan scientific.

Berdasarkan hal tersebut maka perlu dikembangkan perangkat pembelajaran yang membimbing peserta didik untuk merepresentasikan permasalahan ke bentuk matematis, memecahkan permasalahan, bernalar, serta membuat peserta didik aktif dan kreatif dalam proses belajar mengajar di sekolah. Salah satu model pembelajaran yang diharapkan dapat membantu peserta didik dalam membangun kemampuan representasi matematis adalah model pembelajaran berdasarkan masalah atau Problem Based Learning. Problem Based Learning, yang merupakan suatu pendekatan dalam pembelajaran dimana peserta didik dihadapkan pada masalah autentik (nyata) diawal pembelajaran, yang prosedur penyelesaiannya tidak terstruktur dengan baik (tidak procedural), sehingga diharapkan peserta didik dapat menyusun pengetahuan mereka sendiri, mampu berfikir kritis, mampu membangun pengetahuan mereka sendiri dan memiliki kemampuan representasi dalam menyelesaikan masalah (Fitri, Munzir, \& Duskri, 2017). Pernyataan ini diperkuat oleh penelitian yang dilakukan oleh Lilis (2017) yang menyimpulkan bahwa Problem Based Learning dapat meningkatkan kemampuan representasi matematis.

Problem Based Learning sebagai suatu model ke arah penataan pembelajaran yang melibatkan peserta didik untuk menghadapi permasalahan melalui praktik nyata sesuai dengan kehidupan sehari-hari. Peserta didik aktif bekerjasama dalam kelompok untuk mencari solusi permasalahan dunia nyata (Ryanto, 2010). Salah satu materi matematika yang melibatkan kegiatan tersebut adalah menyelesaikan permasalahan sehari-hari yang berkaitan dengan konsep bangun ruang sisi datar. Namun pada kenyataanya peserta didik masih kesulitan dalam menyelesaikannya (Khusnul, 2017). Hal ini sejalan dengan pendapat Resmi (2018) bahwa materi Bangun Ruang Sisi Datar merupakan materi yang sering ditemui peserta didik dalam kehidupan sehari-hari. Walaupun begitu peserta didik masih saja kesulitan dalam menyelesaikan masalah atau soal yang diberikan. Peserta didik kesulitan mengubah soal yang diketahui kedalam bentuk model matematika.

Berdasarkan temuan peneliti yang telah dipaparkan sebelumnya, maka salah satu solusi dalam mengatasi masalah yang ditemukan adalah dengan melakukan pengembangan perangkat pembelajaran matematika berupa Silabus, Rencana Pelaksanaan Pembelajaran (RPP) dan Lembar Kerja Peserta Didik (LKPD) pada materi Bangun Ruang Sisi Datar untuk mengembangkan kemampuan representasi 
Pengembangan Perangkat Pembelajaran Matematika Menggunakan Model Problem Based Learning Untuk Memfasilitasi Kemampuan Representasi Matematis Peserta Didik, Ovemy Delfita, Nahor Murani Hutapea, Atma Murni

matematis peserta didik kelas VIII SMP melalui pembelajaran model Problem Based Learning yang valid dan praktis.

\section{METODE}

Penelitian ini termasuk penelitian pengembangan (research and development). Penelitian pengembangan (research and development) adalah metode penelitian yang digunakan untuk menghasilkan produk tertentu (Sugiyono, 2008). Penelitian ini bertujuan untuk menghasilkan perangkat pembelajaran menggunakan model Problem Based Learning untuk memfasilitasi kemampuan representasi matematis peserta didik pada materi bangun ruang sisi datar yang valid dan praktis.

Penelitian pengembangan mengadaptasi model pengembangan R\&D oleh Borg and Gall yang terdiri dari sepuluh tahapan yaitu (1) Penelitian dan pengumpulan data; (2) Perencanaan; (3) Pengembangan draf produk; (4) Uji coba lapangan awal; (5) merevisi hasil uji coba; (6) Uji coba lapangan; (7) Penyempurnaan produk hasil uji coba lapangan; (8) Uji pelaksanaan lapangan; (9) Penyempurnaan produk akhir; (10) Diseminasi dan implementasi. Prosedur pengembangan dalam penelitian ini hanya sampai pada tahapan ke lima. Tahapan keenam dan seterusnya tidak dapat dilaksanakan karena membutuhkan uji coba dalam sekala besar. Terjadinya virus corona (covid-19) membuat pemerintah memberlakukan proses belajar mengajar secara daring sehingga tidak dapat memaksimalkan uji coba produk dalam skala besar. Penelitian dilakukan sampai tahap praktikalitas perangkat.

Subjek penelitian yaitu subjek uji coba kelompok kecil yang terdiri dari delapan peserta didik kelas VIII SMP N 1 Siak Hulu dengan kemampuan akademis yang heterogen. Instrumen pengumpul data pada penelitian adalah lembar validasi dan angket respon peserta didik. Lembar validasi berisi pernyataan untuk menilai komponen-komponen yang terdapat dalam perangkat pembelajaran. Lembar validasi terdiri dari dua jenis skala yaitu skala Guttman dan skala Likert. Lembar validasi menggunakan skala Guttman dengan kriteria Ya dan Tidak. Lembar validasi menggunakan skala Likert yang terdiri dari empat alternatif jawaban, yaitu 1, 2, 3, dan 4 yang menyatakan sangat tidak sesuai, tidak sesuai, sesuai, dan sangat sesuai. Angket menggunakan skala Likert yang terdiri dari empat alternatif jawaban, yaitu 1, 2, 3, dan 4 yang menyatakan sangat tidak setuju, tidak setuju, setuju, dan sangat setuju.

Teknik analisis data terdiri dari analisis data analisis kevalidan perangkat pembelajaran menggunakan validasi ahli yang dilakukan oleh 3 ahli dalam memberikan penilaian terhadap perangkat yang dikembangkan. Perangkat pembelajaran yang telah divalidasi selanjutnya dianalisis secara deskriptif kualitatif. Data yang tertera pada lembar validasi merupakan penilaian dari masingmasing validator terhadap perangkat pembelajaran dianalisis berdasarkan rata-rata skor.

\section{Tabel 1.}

Kriteria Validitas Perangkat 


\begin{tabular}{|c|c|c|}
\hline No & Rata-rata skor & Tingkat Validitas \\
\hline 1 & $85,01 \%-100,00 \%$ & Sangat Valid \\
\hline 2 & $70,01 \%-85,00 \%$ & Valid \\
\hline 3 & $50,01 \%-70,00 \%$ & Kurang Valid \\
\hline 4 & $01,00 \%-50,00 \%$ & Tidak Valid \\
\hline
\end{tabular}

Tabel 1 adalah kriteria skor validasi perangkat, dimana skor diperoleh dari rata-rata hasil penilaian dari validator. Kriteria perangkat pembelajaran dikatakan valid jika rata-rata skor masing-masing perangkat berada pada kategori minimal Valid.

Analisis kepraktisan perangkat dilakukan dengan melihat hasil angket respon peserta didik. Adapun kriteria praktikalitas perangkat pembelajaran dari pengguna dapat dilihat pada Tabel 2.

Tabel 2.

Kriteria Praktikalitas

\begin{tabular}{|c|l|c|}
\hline No & Tingkat Pencapaian & Tingkat Praktikalitas \\
\hline 1 & $85,01 \%-100,00 \%$ & Sangat praktis \\
\hline 2 & $70,01 \%-85,00 \%$ & Praktis \\
\hline 3 & $50,01 \%-70,00 \%$ & Kurang praktis \\
\hline 4 & $01,00 \%-50,00 \%$ & Tidak praktis \\
\hline
\end{tabular}

Menurut Sa'dun (2013), perangkat pembelajaran dapat digunakan jika tingkat kepraktisan lebih dari $70 \%$.

\section{Hasil}

Produk yang dihasilkan dari penelitian adalah perangkat pembelajaran dengan penerapan Problem Based Learning untuk meningkatkan kemampuan representasi matematis pada materi bangun ruang sisi datar. Perangkat pembelajaran terdiri dari Silabus, Rencana Pelaksanaan Pembelajaran (RPP), dan Lembar Kerja Peserta Didik (LKPD).

Proses pengembangan perangkat pembelajaran melalui lima tahapan. Tahap pertama yaitu tahap penelitian dan pengumpulan data, pada tahap ini peneliti melakukan analisis kebutuhan yang terdiri dari analisis perangkat pembelajaran, analisis materi, dan analisis karakteristik peserta didik. Analisis perangkat pembelajaran dilakukan dengan teknik wawancara dan studi dokumen. Peneliti melakukan wawancara terhadap tiga guru matematika tingkat SMP Negeri di kabupaten Kampar. wawancara yang diberikan terdiri dari beberapa aspek yaitu kurikulum yang diterapkan di sekolah, keterlibatan guru dalam menyusun perangkat, merumuskan tujuan pembelajaran, model pembelajaran yang digunakan, metode pembelajaran yang digunakan, penggunaan LKPD dan karakteristik dan kesulitan peserta didik dalam belajar.

Hasil wawancara diperoleh kesimpulan bahwa $70 \%$ guru cenderung menggunakan perangkat yang diperoleh dari MGMP dan internet. Hal ini disebabkan guru masih kesulitan dalam menyusun perangkat pembelajaran sesuai dengan kurikulum 2013. Dalam kegiatan pembelajaran masih cenderung berpusat kepada guru. Lembar Kerja Peserta Didik yang dibuat guru berisi soal-soal rutin 
Pengembangan Perangkat Pembelajaran Matematika Menggunakan Model Problem Based Learning Untuk Memfasilitasi Kemampuan Representasi Matematis Peserta Didik, Ovemy Delfita, Nahor Murani Hutapea, Atma Murni

yang tidak mengajak peserta didik menemukan konsep pembelajaran matematika, tidak meningkatkan rasa ingin tahu serta tidak membuat peserta didik menjadi mandiri dalam menyelesaikan masalah.

Peneliti kemudian melakukan analisis materi. Berdasarkan hasil analisis perangkat pembelajaran diperoleh bahwa perangkat pembelajaran yang disusun oleh guru untuk materi bangun ruang sisi datar terdiri dari enam pertemuan yaitu: (1) luas permukaan kubus dan balok; (2) luas permukaan prisma; (3) luas permukaan limas; (4) volume kubus dan balok; (5) volume prisma; dan (6) volume limas. Materi pembelajaran yang disusun belum sesuai dengan ketercapaian KD. Analisis karakteristik peserta didik dilaksanakan terhadap peserta didik kelas VIII SMP Negeri 1 Siak Hulu. Analisis peserta didik bertujuan untuk mengetahui karakteristik peserta didik dalam mengikuti proses pembelajaran dan kemampuan yang harus dimiliki peserta didik. Hasil observasi menunjukkan bahwa peserta didik memerlukan bantuan untuk mengembangkan kemampuan kognitif dengan memfasilitasi modell pembelajaran yang berisi siswa untuk belajar secara mandiri dan menemukan konsep pembelajaran.

Tahap perencanaan, peneliti selanjutnya merancang perangkat pembelajaran matematika pada materi bangun ruang sisi datar menggunakan model Problem Based Learning untuk memfasilitasi kemampuan representasi matematis. Peneliti merancang format perangkat pembelajaran yang terdiri dari tiga komponen, yaitu Silabus, RPP, dan LKPD pada materi bangun ruang sisi datar sesuai dengan KD 3.9 dan 4.9.

Tahap pengembangan perangkat pembelajaran, peneliti mengembangkan perangkat pembelajaran berdasarkan rancangan yang telah disusun. Perangkat pembelajaran yang dikembangkan terdiri dari Silabus, RPP, dan LKPD dengan menerapkan model Problem Based Learning untuk meningkatkan kemampuan representasi matematis pada materi bangun ruang sisi datar. Perangkat yang telah dikembangkan divalidasi oleh tiga orang ahli yaitu dua Dosen Pendidikan matemtika Universitas Islam Riau dan satu orang Dosen Pascasarjana Universitas Riau. Hasil validasi terhadap silabus, RPP, dan LKPD dari tiga validator dapat dilihat pada Gambar. 1, Gambar.2, dan Gambar.3 berikut ini:

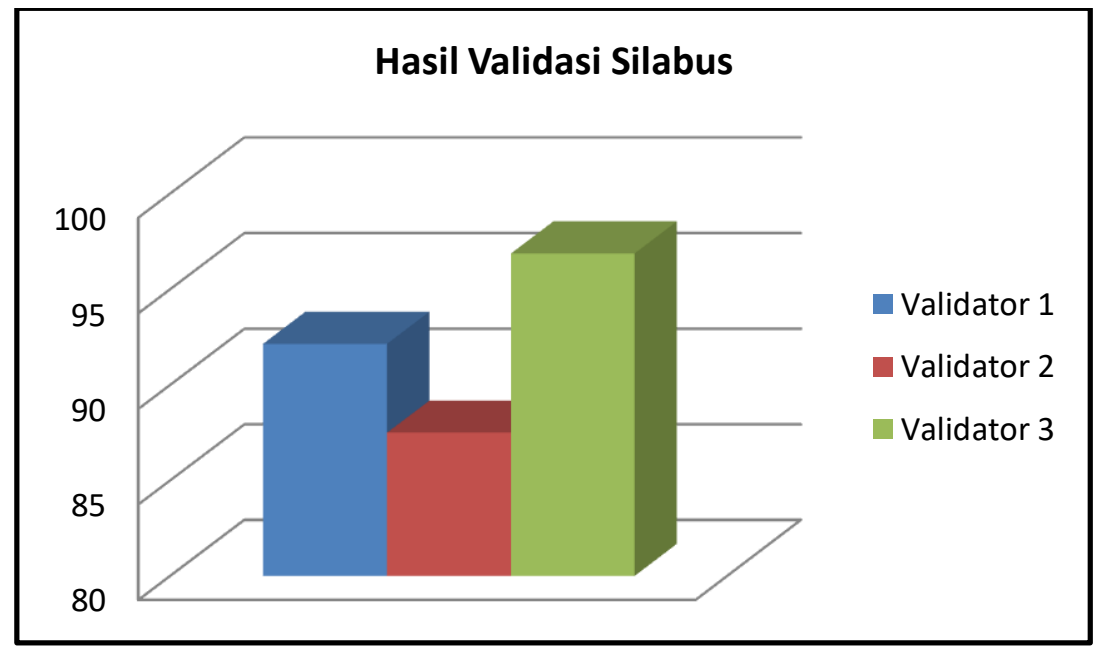


Gambar 1. Hasil Validasi Silabus

Hasil validasi menunjukkan bahwa silabus memenuhi kriteria sangat valid dengan persentase rata-rata dari Validator-1 yaitu 92,18\%, Validator-2 yaitu 87,5\%, dan Validator-3 yaitu 96,875\%.

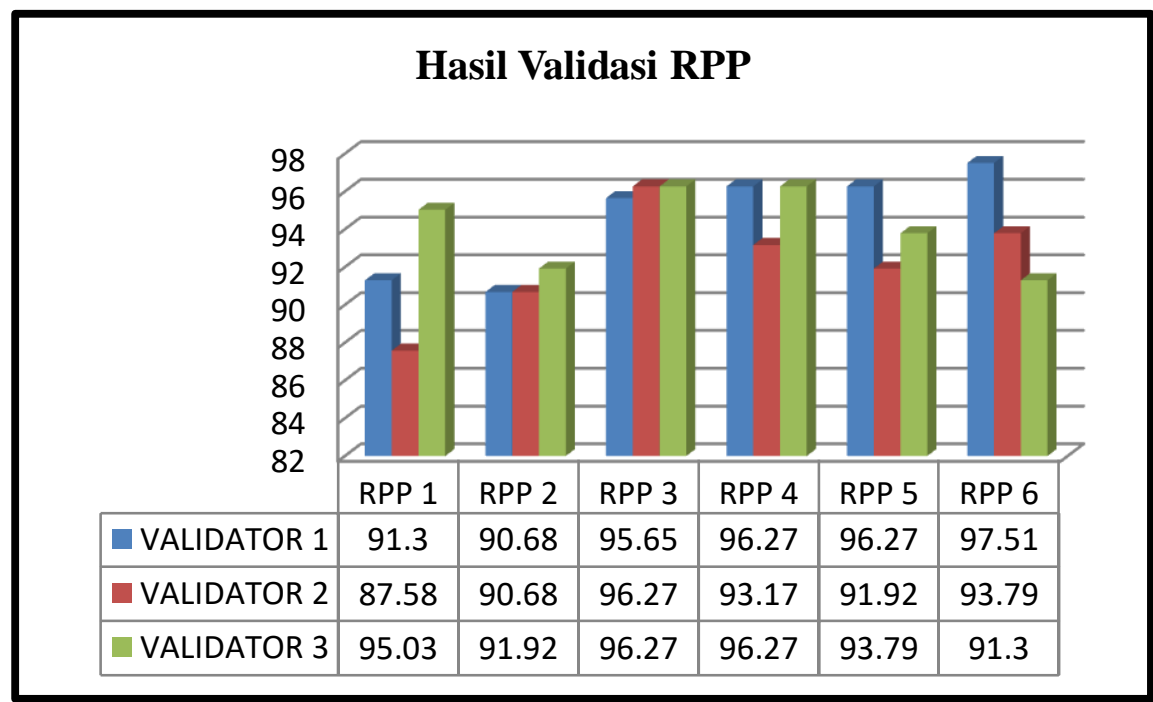

Gambar 2. Hasil validasi RPP

Gambar 2 menunjukan bahwa RPP untuk lima pertemuan memenuhi kriteria sangat valid dengan persentase rata-rata dari Validator-1 yaitu 94,61\%, Validator-2 yaitu 92,23\%, dan Validator-3 yaitu 94,09\%. Validator memberikan beberapa saran terhadap RPP yang dikembangkan yaitu perbaikan KKO pada IPK yang tidak sesuai KD, rumusan tujuan pembelajaran harus disesuaikan dengan IPK, dan penambahan gambar kegiatan LKPD pada RPP.

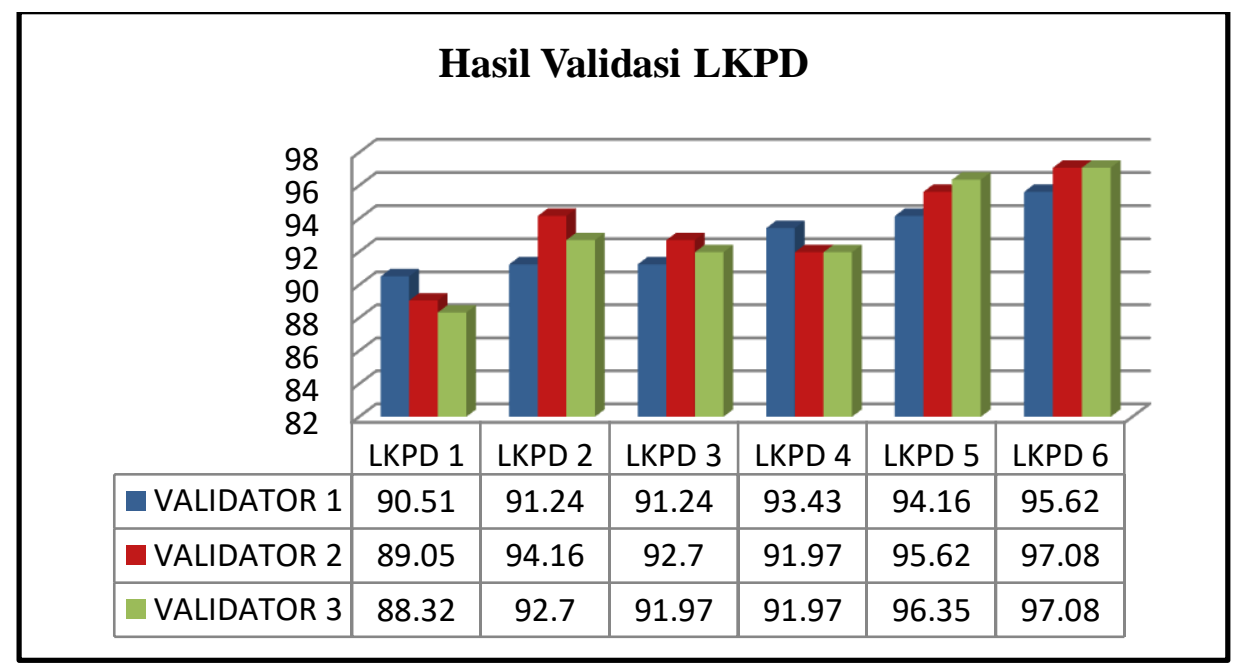

Gambar 3. Hasil validasi RPP

Hasil validasi menunjukkan bahwa LKPD untuk enam pertemuan memenuhi kriteria sangat valid dengan persentase rata-rata dari Validator-1 yaitu 92,7\%, Validator-2 yaitu 93,43\%, dan 
Pengembangan Perangkat Pembelajaran Matematika Menggunakan Model Problem Based Learning Untuk Memfasilitasi Kemampuan Representasi Matematis Peserta Didik, Ovemy Delfita, Nahor Murani Hutapea, Atma Murni

Validator-3 yaitu 93,06\%. Validator memberikan beberapa saran perbaikan pada LKPD yang dikembangkan yaitu gambar yang terdapat pada Cover LKPD sebaiknya disesuaikan dengan gambar pendukung yang terdapat pada orientasi pada masalah, tujuan yang terdapat pada setiap cover LKPD harus disesuaikan dengan IPK.

Berdasarkan hasil validasi oleh tiga validator menunjukkan bahwa perangkat pembelajaran menggunakan model Problem Based Learning untuk meningkatkan kemampuan representasi matematis peserta didik pada bangun ruang sisi datar yang dikembangkan memenuhi kriteria valid. Perangkat yang dikembangkan telah memenuhi kriteria valid maka dapat diujicobakan dalam proses pembelajaran (Muhamad, 2019).

Tahap uji coba terbatas, pada tahap ini perangkat pembelajaran yang telah memenuhi kriteria valid diujicobakan kepada delapan peserta didik kelas VIII SMP Negeri 1 Siak Hulu. Peserta didik dibagi menjadi empat kelompok dengan kemampuan yang heterogen. Pada uji coba terbatas peserta didik diberikan LKPD. Tampilan LKPD yang berbeda dari LKPD Guru sebelumnya, membuat peserta didik tertarik untuk mengerjakannya.

Peneliti memberikan LKPD-1 tentang luas permukaan kubus dan balok. Tahap pertama pada LKPD-1 peserta didik dihadapkan pada masalah kontekstual. Peserta didik kemudian mencermati permasalahan. Tahap kedua yaitu pengorganisasian peserta didik, Tahap kedua yaitu mengorganisasikan peserta didik. Bersama kelompoknya peserta didik menuliskan informasi apa yang diketahui dan ditanyakan pada masalah. melibatkan kemampuan representasi verbalnya. Kemampuan representasi verbal yaitu menafsirkan atau menuliskan interpretasi dari suatu masalah dengan menggunakan bahasa sendiri (Indri, 2018). Berikut adalah salah satu hasil pekerjaan peserta didik untuk kemampuan representasi verbalnya.

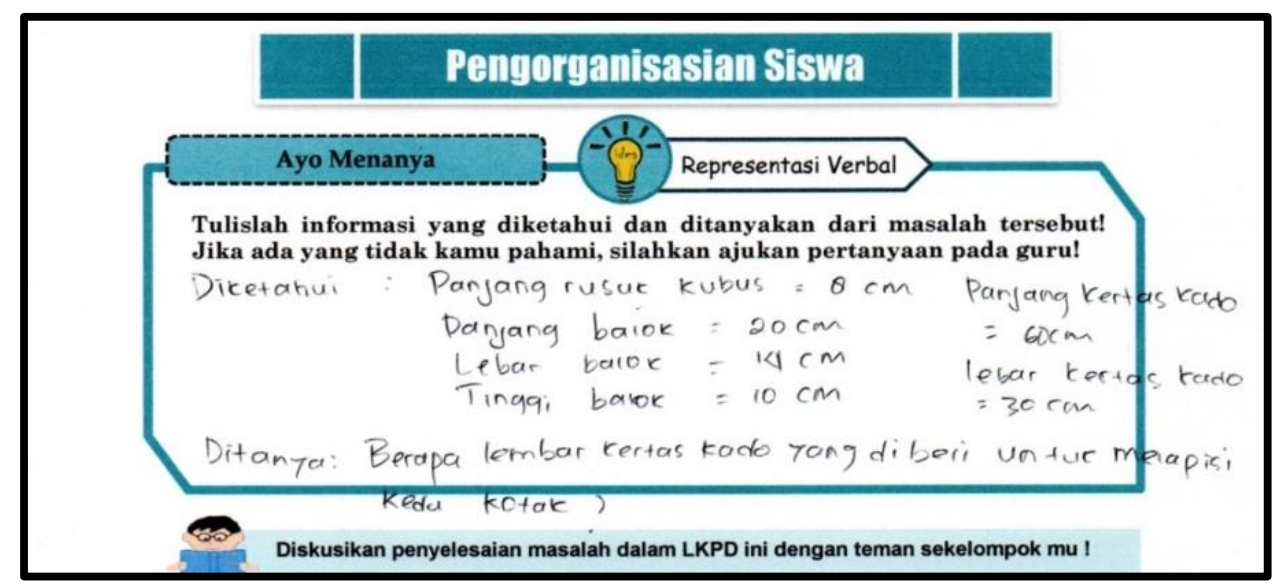

Gambar 4. Kemampuan verbal peserta didik

Gambar 4 menunjukkan bahwa kemampuan verbal peserta didik sudah tergolong baik. Peserta didik mampu menafsirkan masalah dengan menggunakan bahasa sendiri.

Tahap ketiga pada LKPD yaitu penyelidikan kelompok. Peserta didik mengumpulkan dan mengolah informasi yang dibutuhkan dalam menyelesaikan masalah. Pada tahap ini peserta didik 
melatih kemampuan representasi visual dan simboliknya. Kemampuan visual yaitu kemampuan peserta didik mengubah masalah kedalam bentuk gambar dan kemampuan simbolik yaitu kemampuan peserta didik membuat model matematik dari suatu masalah (Indri, 2018). Berikut adalah salah satu hasil pekerjaan peserta didik untuk kemampuan representasi visual dan simbolik.

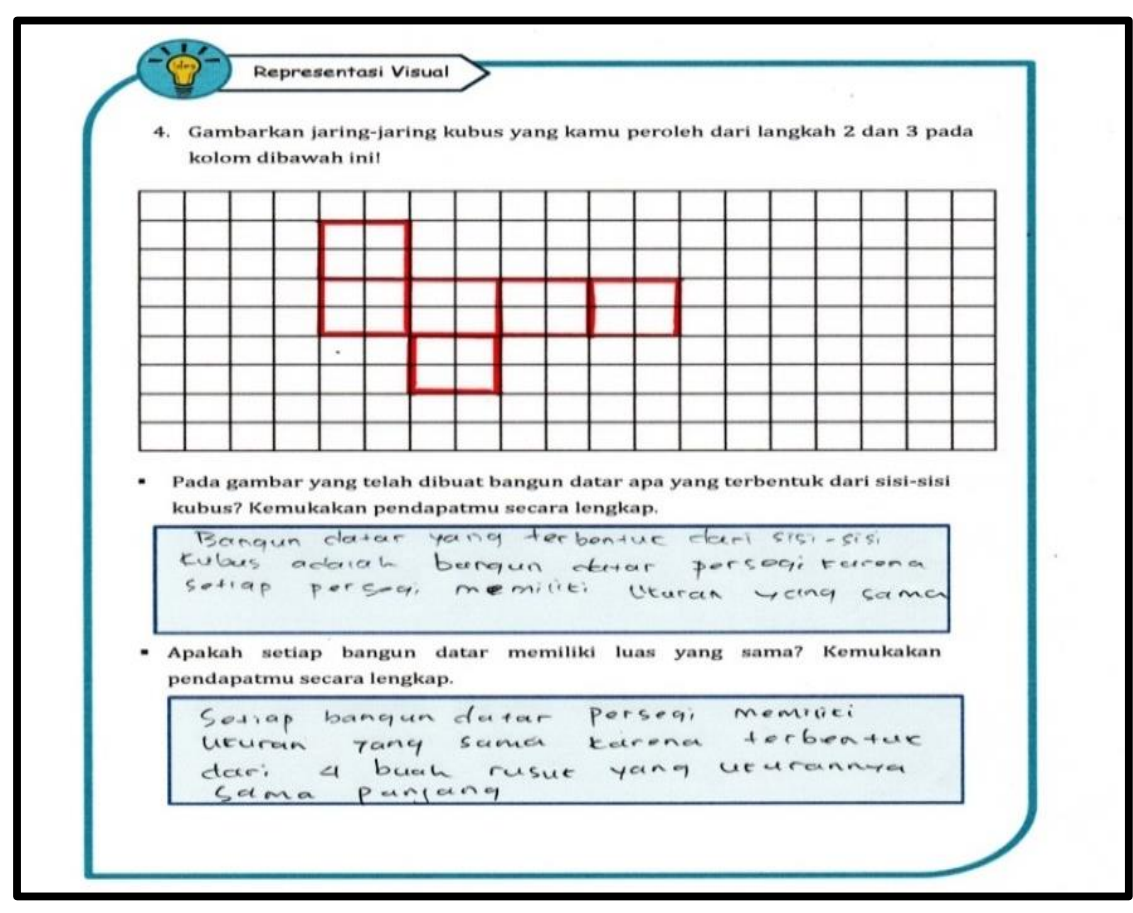

Gambar 5. Kemampuan visual peserta didik

Gambar 5 merupakan hasil pekerjaan peserta didik membuat gambar jaring-jaring kubus dari proses pengumpulan data yang telah dilakukan.

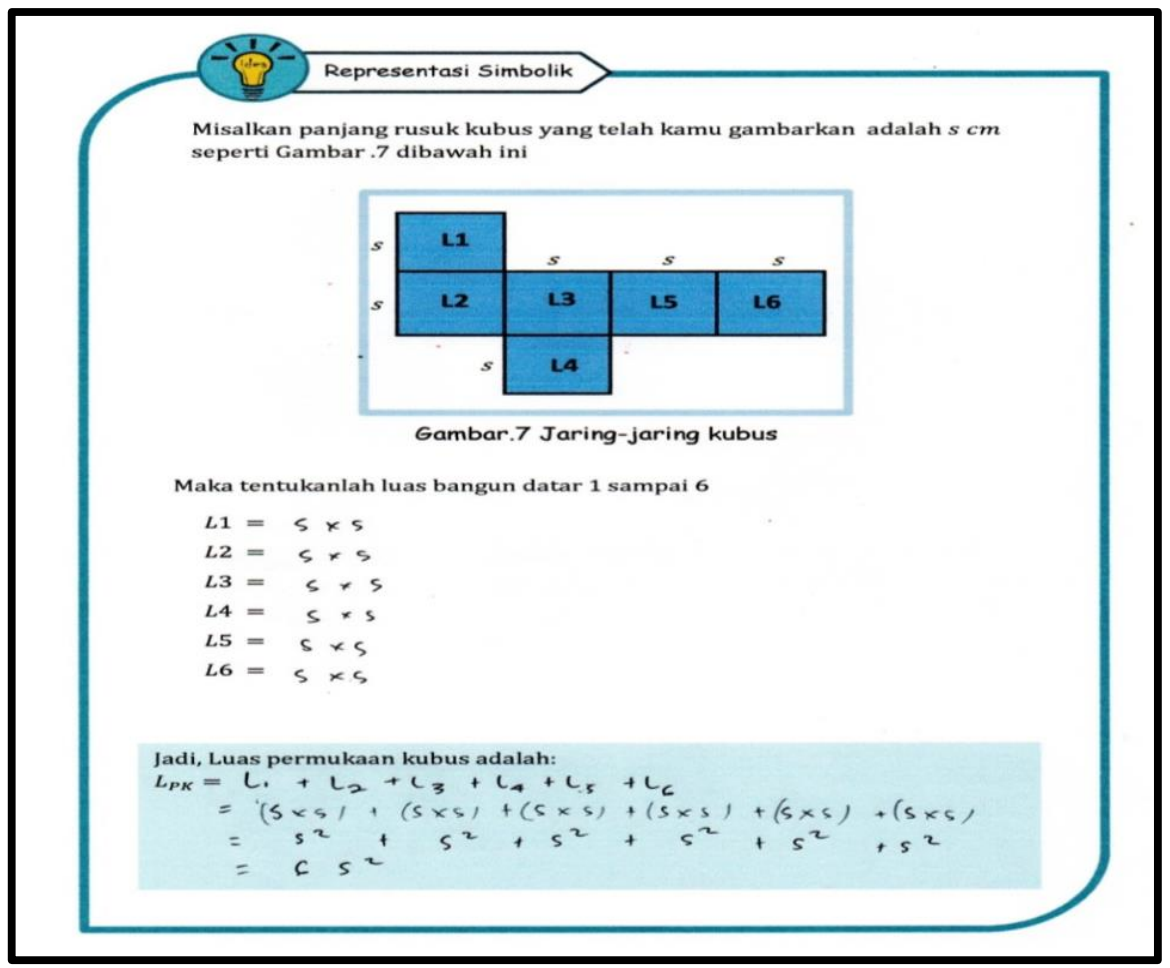


Pengembangan Perangkat Pembelajaran Matematika Menggunakan Model Problem Based Learning Untuk Memfasilitasi Kemampuan Representasi Matematis Peserta Didik, Ovemy Delfita, Nahor Murani Hutapea, Atma Murni

Gambar 6. Kemampuan representasi simbolik peserta didik

Pada Gambar 6 terlihat bahwa peserta didik mampu menginterpretasikan masalah kedalam simbolik.

Setelah mengumpulkan informasi, peserta didik dapat menyelesaikan masalah yang telah mereka cermati diawal. Peserta didik dapat mengembangkan kemampuan representasi mereka secara mandiri dari permasalahan tersebut. Gambar 7 merupakan hasil pekerjaan peserta didik.

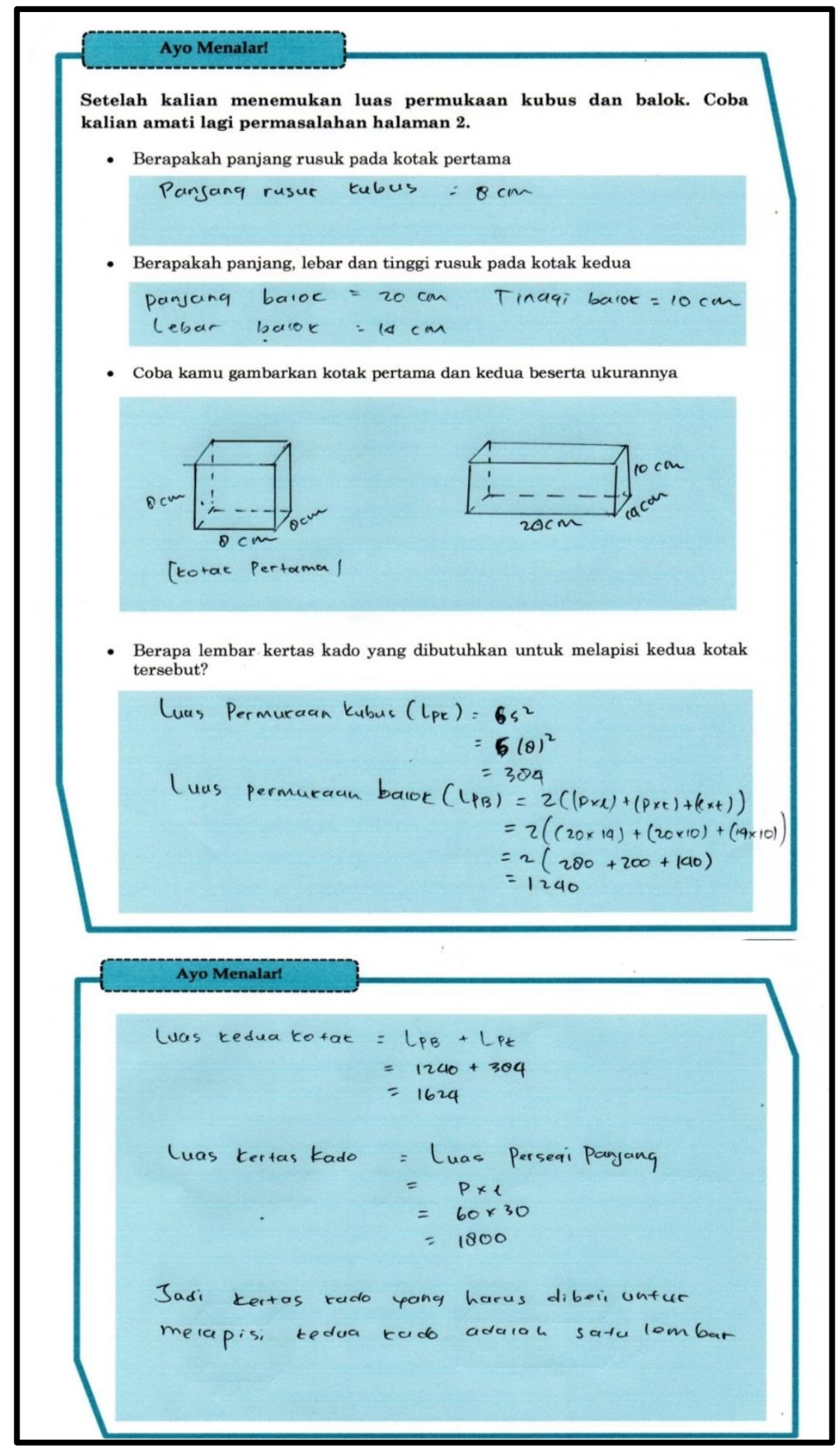




\section{Gambar 7. Kemampuan Representasi Peserta Didik}

Hasil pekerjaan peserta didik pada Gambar 7 dapat dinyatakan bahwa bahwa kemampuan verbal peserta didik sudah terdolong baik. Peserta didik mampu menafsirkan masalah dengan menggunakan bahasa sendiri. Sejalan dengan penelitian yang telah dilakukan oleh Vania (2019) reprentasi verbal dilihat dari kemampuan peserta didik menginterpretasikan masalah kedalam bentuk kata-kata. Peserta didik juga sudah mampu menggunakan kemampuan visualnya. Peserta didik dapat membuat gambar bangun ruang sisi datar yang dimaksud pada soal dengan ukuran yang telah ditentukan untuk memperjelas soal dan peserta didik dapat menyajikan kembali permasalahan kedalam bentuk gambar. Sejalan dengan penelitian yang dilakukan oleh Vania (2019) bahwa kemampuan visual peserta didik dapat dilihat dari kemampuan peserta didik dalam menginterpretasikan masalah kebentuk gambar guna memfasiliatasi permasalahan.

Kemampuan representasi simbolik peserta didik sudah baik. Peserta didik mengubah masalah kedalam bentuk simbolik. Sejalan dengan penelitian Vania (2019) kemampuan representasi simbolik dilihat dari interpretasi masalah kedalam bentuk simbolik. Namun terdapat kesalah peserta didik dalam menentukan luas permukaan pada kotak pertama atau kubus. Peserta didik salah dalam menentukan rumusnya. Peserta didik menghitung 6 sisi pada kotak pertama, seharusnya peserta didik hanya menghitung 5 sisi. Pada kotak pertama bagian atas dari kotak tidak dilapisi kertas kado. Sehingga peneliti menjelaskan kembali mengenai luas permukaan kubus kepada peserta didik.

Setiap LKPD yang peneliti berikan memuat soal yang dapat melatih peserta didik dalam kemampuan representasinya. Tahapan LKPD-2 sampai dengan LKPD-6 sama dengan LKPD-1. Peserta didik diarahkan untuk mengembangkan kemampuan representasi matematisnya. Setelah peserta didik mengerjakan LKPD, peserta didik diberikan angket respon untuk melihat kepraktisan penggunaan LKPD.

Hasil analisis terhadap angket respon peserta didik menunjukkan LKPD memenuhi kriteria sangat praktis dengan persentase LKPD-1 yaitu 88,62\%, LKPD-2 yaitu 93,30\%, LKPD-3 yaitu 91,96\%, LKPD-4 yaitu 93,30\%, LKPD-5 yaitu 92,86\% dan LKPD-6 yaitu 93,30\%. Perangkat pembelajaran dikatakan praktis jika persentase kepraktisan lebih dari 70\% (Akbar, 2013). Penelitian yang telah dilaksanakan oleh Muyati (2015) menunjukkan bahwa tingkat praktikalitas perangkat pembelajaran mencapai katagori baik yaitu lebih dari $80 \%$. Berdasarkan penelitian sebelumnya maka dapat dikatagorikan perangkat peneliti telah memenuhi kriteria praktikalitas sehingga perangkat pembelajaran layak digunakan.

Tahap revisi produk, pada tahap ini peneliti merevisi LKPD berdasarkan hasil uji coba terbatas yang telah dilaksanakan. Terdapat beberapa masukan untuk LKPD yaitu kolom yang disediakan bagi peserta didik untuk menuliskan jawaban terlalu kecil sehingga tulisan mereka harus keluar dari kolom yang disediakan. Peserta didik merasa kesulitan dalam menemukan rumus volume 
Pengembangan Perangkat Pembelajaran Matematika Menggunakan Model Problem Based Learning Untuk Memfasilitasi Kemampuan Representasi Matematis Peserta Didik, Ovemy Delfita, Nahor Murani Hutapea, Atma Murni

limas yang berkaitan dengan volume kubus karena pada LKPD diberikan tabel dan gambar kubus yang peserta didik kurang pahami dalam menyelesaikannya

\section{KESIMPULAN}

Berdasarkan hasil penelitian pada pembahasan sebelumnya, dapat disimpulkan bahwa pengembangan perangkat pembelajaran melalui model pengembangan Borg and Gall menghasilkan perangkat pembelajaran yang valid dan praktis. Perangkat pembelajaran yang dikembangkan berupa Silabus, RPP, dan LKPD menggunakan model Problem Based Learning untuk memfasilitasi kemampuan representasi matematis peserta didik pada materi bangun ruang sisi datar.

Rata-rata hasil validasi dari tiga validator menunjukkan bahwa Silabus, RPP, dan LKPD yang dikembangkan memenuhi kriteria sangat valid. Sedangkan kepraktisan perangkat pembelajaran dilihat dari hasil angket respon peserta didik terhadap penggunaan LKPD. Rata-rata hasil angket respon peserta didik terhadap LKPD menunjukkan memenuhi kriteria sangat praktis.

\section{DAFTAR PUSTAKA}

Fitri, N., Munzir, S., \& Duskri, M. (2017). Meningkatkan Kemampuan Representasi Matematis melalui Penerapan Model Problem Based Learning. Jurnal Didaktik Matematika, 4(1), 59-67. https://doi.org/10.24815/jdm.v4i1.6902

Inayah, S. (2018). Penerapan Pembelajaran Kuantum Untuk Meningkatkan Kemampuan Pemecahan Masalah Dan Representasi Multipel Matematis Siswa. KALAMATIKA Jurnal Pendidikan Matematika, 3(1), 1-16.

Lilis Kurnianingsih . (2017). Aplikasi Pembelajaran Berbasis Masalah ( Problem Based Learning ) Untuk Meningkatkan Kemampuan Representasi Matematis Siswa Tentang Persamaan Linier Dua Variabel. $M P D, 8(1): 54-59$.

Permendikbud No. 58 Tahun 2014. Kurikulum 2013 Sekolah Menengah Pertama Madrasah Tsanawiyah. Kemendikbud. Jakarta.

Riyanto Yatim. 2010. Paradigma Baru Pembelajaran: Sebagai Referensi bagi Guru/ Pendidik dalam Implementasi Pembelajaran yang Efektif dan Berkualitas. Surabaya: Kencana Prenada Media Group.

Murni, A. (2012). Peningkatan kemampuan representasi matematis siswa smp melalui pembelajaran metakognitif dan pembelajaran metakognitif berbasis softskill. Pendidikan, 4 No 2(November), 978-979.

Sa'dun Akbar. 2013. Instrumen Perangkat Pembelajaran. Bandung: Remaja Rosdakarya.

Simanungkalit, R. H. (2016). Pengembangan Perangkat Pembelajaran Untuk Meningkatkan Kemampuan Pemecahan Masalah Matematis Siswa Smp Negeri 12 Pematangsiantar. Journal of Mathematics Education, Science and Technology, 1(1), 39-56. 
Tanjung, H. S., \& Nababan, S. A. (2018). matematika berorientasi model pembelajaran berbasis masalah ( pbm ) untuk meningkatkan kemampuan berpikir kritis siswa sma se-kuala nagan raya aceh, ix(2). Genta Mulya. Volume Ix No. 256-70.

Wardhani, Sri dan Rumiati. 2011. Instrumen Penilaian Hasil Belajar Matematika SMP: Belajar dari PISA dan TIMSS. Yogyakarta: Badan Pengembangan Sumber Daya Manusia Pendidikan dan Penjaminan Mutu Pendidikan. http://p4tkmatematika.org. 